\title{
Taxonomy, Recollection and Conservation Implications of Aquilaria khasiana (Thymelaeaceae): An endemic and threatened species of India
}

\author{
Aabid Hussain Mir ${ }^{1}$, Dilip Kumar Roy ${ }^{2}$ and Krishna Upadhaya ${ }^{3 *}$ \\ 'Department of Environmental Studies, North-Eastern Hill University, Shillong - 793022, Meghalaya, India. \\ ${ }^{2}$ Botanical Survey of India, Eastern Regional Centre, Shillong - 793003, Meghalaya, India. \\ ${ }^{3}$ Department of Basic Sciences and Social Sciences, North-Eastern Hill University, Shillong - 793022, \\ Meghalaya, India. \\ *E-mail: upkri@yahoo.com
}

\begin{abstract}
Aquilaria khasiana Hallier $f$. is found only in Meghalaya in India and was thought to be eliminated from the state. It has been recollected after a gap of 74 years from Mawsynram area of Meghalaya, northeast India. Detailed description, photographs, notes on distribution and ecology are provided here. Conservation measures for this endemic and rare species are also proposed based on the field observation.
\end{abstract}

Keywords: Agarwood, Community Forest, Conservation, Endemic

\section{Introduction}

Aquilaria Lam., a genus of the family Thymelaeaceae comprises about 22 species, distributed in Bhutan, Cambodia, China, northeast India, Laos, Malaysia, Myanmar, Thailand and Vietnam (Kiet et al., 2005). In India, the genus is represented by three species namely A. khasiana Hallier f., A. macrophylla Miq. and A. malaccensis Lam. Of these, A. khasiana is restricted to Khasi hills of Meghalaya and $A$. macrophylla is restricted to the Nicobar Islands (Saikia \& Khan, 2013). Members of this group are considered to be very precious because of their pronounced economic importance as the sources of agarwood, a highly prized aromatic resin produced in the wood on injury. Agarwood is traded under various names (gaharu, agarwood, aloeswood, eaglewood) and used for incense, perfumes, medicines, aromatherapy and religious ceremonies (Ito \& Honda, 2005).

Aquilaria khasiana Hallier $\mathrm{f}$. is exclusively endemic to the state of Meghalaya, India and was first described by Hallier (1922) based on the collections made during the years $1848-1851$ by Hooker and Thomson from Khasia Hills (Hou, 1964). After the type specimens, only two collections from Umteswar forest (S.R. Sarma 12036, ASSAM!) in 1932 and from Umsaw forest (S.R. Sarma 21453, ASSAM!) in 1942 have been made in the state.
Despite many floristic studies carried out in the state, the species could not be collected since last 74 years. Haridasan \& Rao (1985) assess this species as "Rare". The species has also been listed in Appendix II of the Convention on International Trade in Endangered Species of Wild Fauna and Flora (CITES). Though, Kanjilal et al. (1940) and Joseph (1982) made taxonomic publications on A. khasiana based only on the earlier collections, but none of them including protologue have detailed description. The current paper addresses recollection, revised taxonomy, identifies the threats operating and suggests conservation measures of this endemic and rare species. Thus the present collection not only comprises the third authentic report of this species after a lapse of almost 74 years, but also confirms its existence in the natural habitat in the state.

While carrying out floristic studies in Khasi hills some specimens belonging to genus Aquilaria were collected from Mawkasain $\left(25^{\circ} 15.674^{\prime} \mathrm{N} ; 91^{03} 30.850^{\prime}\right.$ E, 1106 m), Mawsynram area of Meghalaya (Fig. 1). After detailed scrutiny, the species was identified as A. khasiana, and further it was confirmed by consultation of published literature (Hallier, 1922; Kanjilal et al., 1940; Joseph, 1982) and comparing with the herbarium specimens housed at ASSAM. The voucher specimens are submitted at ASSAM. The conservation status of the species has been 


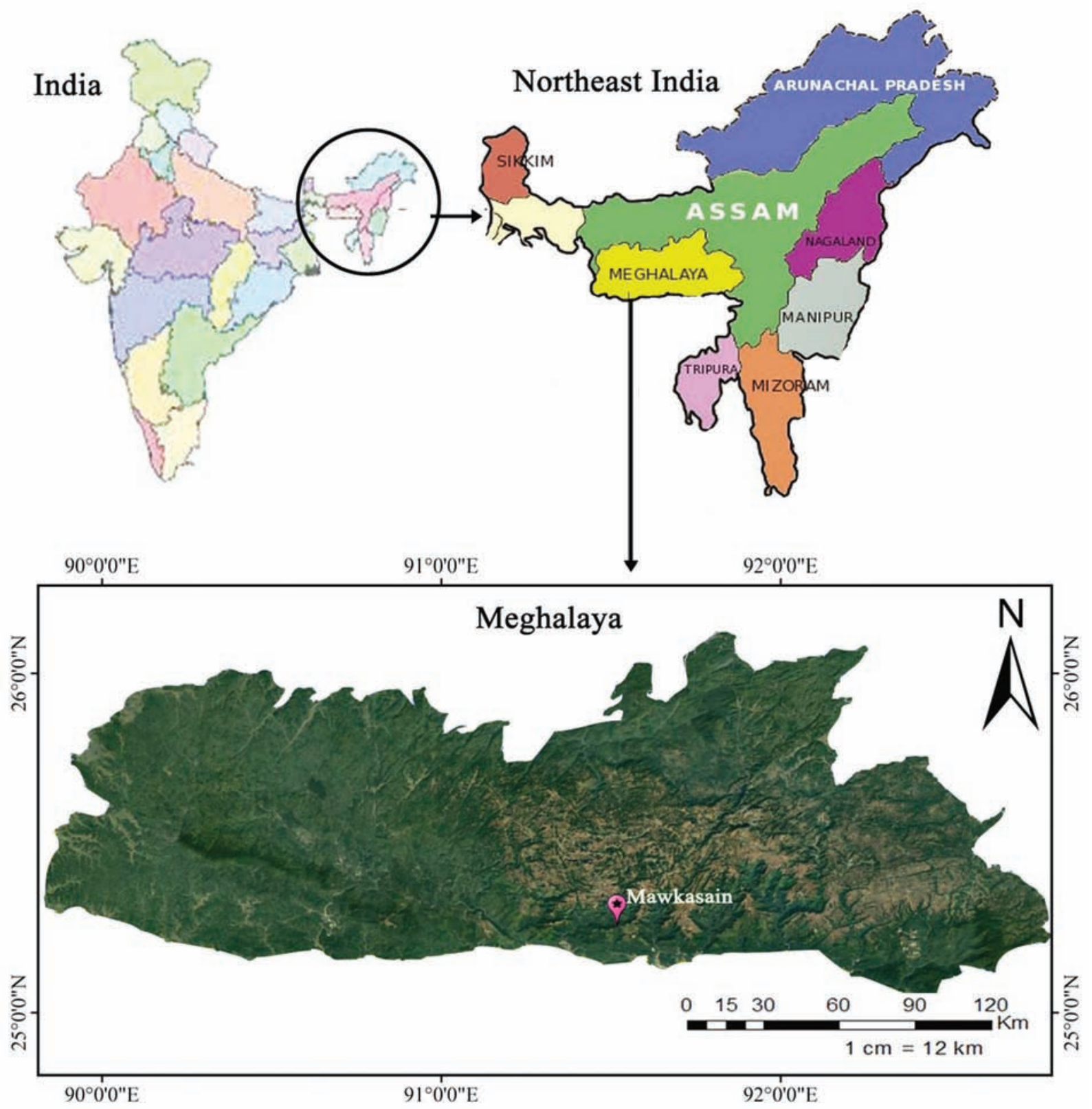

Fig. 1. Distribution of Aquilaria khasiana.

assessed by using IUCN Categories and Criteria (IUCN, 2016).

Aquilaria khasiana Hallier f., Meded. RijksHerb. 44: 18. 1922; Kanjilal et al., Fl. Assam 4: 113. 1940; J. Joseph, Fl. Nongpoh: 228. 1982.

Fig. 2

Evergreen shrub or small tree, to $5 \mathrm{~m}$ high; branchlets sparsely setose when young. Leaves alternate, shortly petioled; petioles $4-5 \mathrm{~mm}$ long, ribbed beneath, setose; blades obovate- oblanceolate or oblong-elliptic, 8-17 $\times 3-5.5 \mathrm{~cm}$, base acute, apex long-acuminate (acumen to $1.5 \mathrm{~cm}$ long), glabrous except the midvien beneath, dark green above, pale green beneath; midrib sparsely appressed-hairy beneath, depressed above; secondary veins close, parallel. Inflorescence a fascicle, terminal or extra-axillary, subsessile, pubescent, 10-flowered. Flowers 1.6-2 × 0.5-0.6 $\mathrm{cm}$; hypanthium cylindrical, 10-ribbed outside; pedicels silky-villous, $0.7-1 \mathrm{~cm}$ long, $0.5-0.7 \mathrm{~mm}$ 


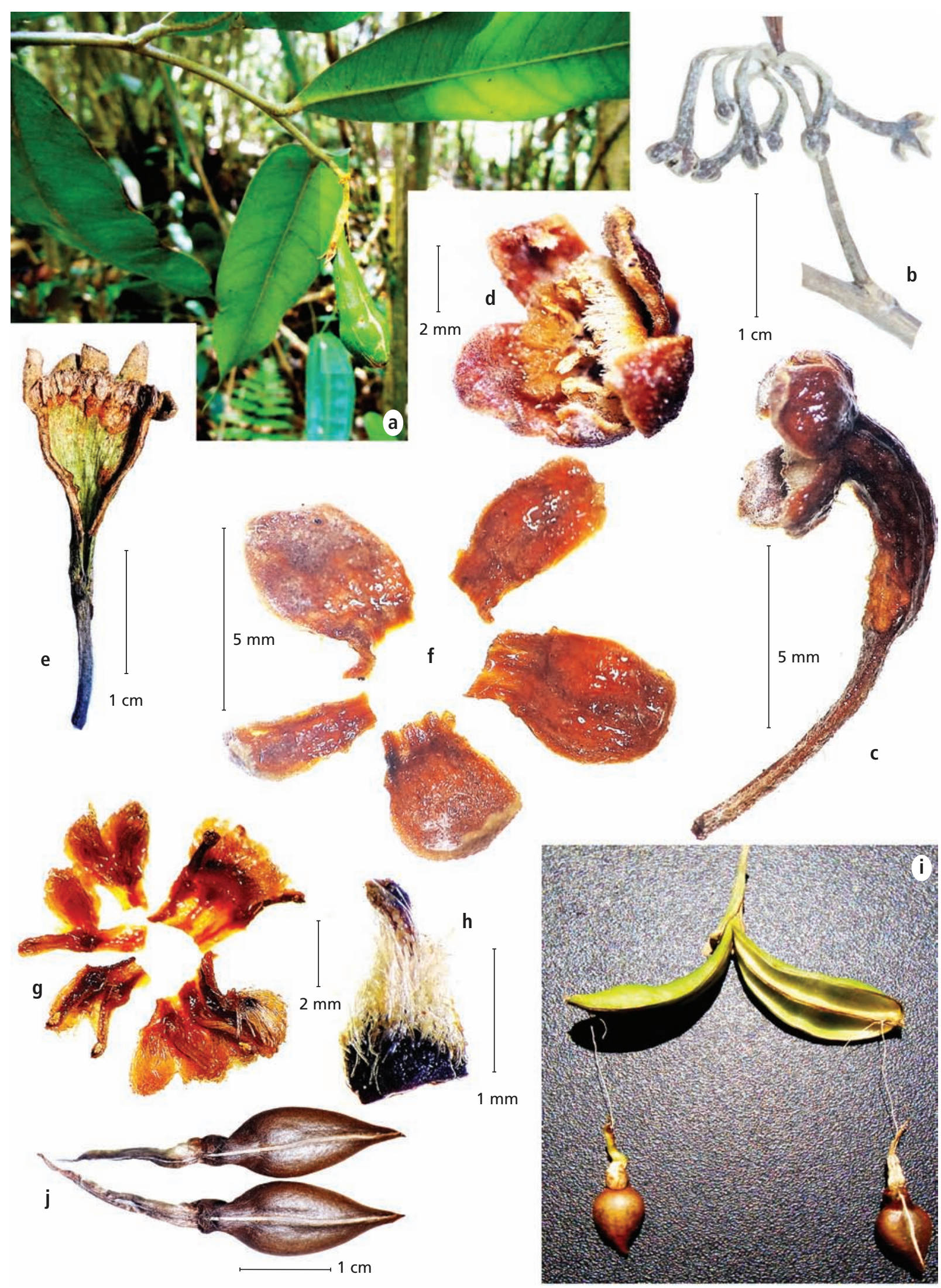

Fig. 2. Aquilaria khasiana Hallier f.: a. A fruiting-twig; b. Inflorescence; c,d. A flower (side and frontal views); e. Split floral tube (hypanthium) showing the placement of petaloid appendages; f. Calyx lobes (ventral view); g. Petaloid appendages along with stamens; h. Gynoecium; i. Fruit with open valves and hanging seeds; j. Seeds (ventral view). 
wide. Calyx tube (hypanthium) cylindrical, $0.8-1$ $\mathrm{cm}$ long, $1.8-2 \mathrm{~mm}$ wide, distinctly 10-ribbed, silky-villous, 4 or 5-lobed, splitting on one side on fruiting; lobes ovate-triangular, 2.8-3.2 × 1.2-2.5 $\mathrm{mm}$, apex acute, about three times shorter than tube, silky-villous outside, greyish tomentose inside. Petaloid appendages distinct, twice as many as calyx lobes, erose, inserted at the base of calyx lobes, to $2 \mathrm{~mm}$ long. Stamens 8-10, sessile; anthers dorsifixed, bilobed, 1-1.5 mm long, introrse. Ovary sessile, ovoid, c. $1 \mathrm{~mm}$ in diam., silky-velutinous, 2-loculed; ovule 1 per cell, hanging near the top of the ovary; style cylindric, c. $0.8 \mathrm{~mm}$ long; stigma capitate. Fruits obovate to oblanceolate, $3-4 \times 1-1.3 \mathrm{~cm}$, apex obtuse to acute, more or less compressed, longnarrowed towards base into a $1-1.5 \mathrm{~cm}$ long stipe, silky-villous when young, later glabrescent, smooth, green on fresh; hypanthium (floral tube) persistent; valves 2 , thick, angle of dehiscence to $180^{\circ}$ on maturity; seeds 2 , ovoid-ellipsoid, 1-1.2 $\times 0.5-0.6 \mathrm{~cm}$, dark brown, puberulous, apex acuminate, base attenuate and elongate into a slender appendage; appendage 0.9-1.2 cm long, twisted when dry, covered with silky hairs.

Flowering: May-July; Fruiting: July-September.

Distribution: India (Meghalaya). Endemic.

Specimens examined: INDIA, Meghalaya: Umteswar forest, 7.7.1935, S.R. Sarma 12036 (ASSAM); Umsaw forest, 16.7.1942, S.R. Sarma 21453 (ASSAM); Khasi hills, Mawsynram, Mawkasain, 20.9.2016, A.H. Mir 90340 (ASSAM).

Ecology and Population: The habitat of the species is represented by subtropical broad-leaved dense evergreen forest with short stature, and the height of the trees rarely exceeds $18 \mathrm{~m}$ (Upadhaya, 2015). Under the 'Koppen climate classification', the region feature in 'subtropical highland climate' with an extraordinarily rainy and lengthy monsoonal season. The species was found to grow in association with Acronychia pedunculata (L.) Miq., Castanopsis tribuloides (Sm.) DC., Calophyllum polyanthum Choisy, Camellia cauduca C.B. Clarke ex Brandis, Cinnamomum tamala T. Nees \& Eberm., Eurya acuminata DC., Garcinia anomala Planch. \& Triana, Litsea elongata (Nees) Hook.f., Lithocarpus dealbatus (Hook.f. \& Thwaites ex Miq.) Rehder, Macaranga denticulata (Blume) Müll.Arg. and Syzygium tetragonum (Wight) Kurz. The species was collected from Mawkasain in Mawsynram area of Khasi hills. The population size of the species was very small and represented by a total of nine individuals. This includes one mature individual, which was cut from ground ( $\approx 20 \mathrm{~cm}$ high), with collar diameter of $23 \mathrm{~cm}$. This cut stump had three sprouts. There were two saplings ( $\geq 1 \mathrm{~m}$ high) and six seedlings ( $\leq 1 \mathrm{~m}$ high).

Threat Status and Conservation Implications: Anthropogenic disturbances in the form of extraction of timber and non-timber forest produces, building roads and forest fires are the major threats to the species. The geographical range of the species is very narrow with an extent of occurrence (EOO) estimated to be $<100 \mathrm{~km}^{2}$ and an area of occupancy (AOO) $<10 \mathrm{~km}^{2}$. On the basis of IUCN (2016) classification criteria, the species is classified as Critically Endangered (CR) as it fulfils the criteria under categories CR (A2, B2, D). The very small population of the species could be attributed to the habitat loss due to human disturbances. Recruitment limitation (failure of seedlings to survive) could be another possible reason for its low population. The species was observed to fruit during the month of September and the seeds were soon exposed to dry environmental conditions (October-February). Moisture stress has been identified as one of the important environmental conditions that hampers the natural regeneration and keeps the population of plant species low as also observed in some endemic and threatened species of the region (Mir et al., 2016; Upadhaya et al., 2017). Moreover, the seeds as well as the seedlings are exposed to forest fire which is quite common during the months of February-March in the area. Such a disturbance-linked decline in population size has also been observed in other threatened species of the state such as Ilex khasiana C.S. Purkay. (Upadhaya et al., 2009) and Magnolia lanuginosa (Wall.) Figlar \& Noot. (Mir et al., 2016).

The low population of the species and its occurrence in fragmented and disturbed habitats warrant urgent conservation initiatives in order to prevent it from extinction. The habitat of the species needs to be strictly protected and the population has to be monitored. Forest fires, cutting of trees and construction of roads are rapidly contributing to its habitat degradation and fragmentation, which also need to be checked. The species also requires a detailed survey to determine its geographical range and better understanding of the population size. Along with in situ conservation, ex situ conservation programmes including multiple propagation of this species using tissue culture technique should be undertaken. The raised plantlets shall be introduced in botanical gardens and in agroforestry activities. Like its allied species, the plant can be of great economic value, if it's potential for making perfumes and medicine is explored. 


\section{Acknowledgements}

We are thankful to the local traditional heads for allowing us to work in the forests under their control. The help and cooperation received from Dr. A.A. Mao, Scientist \& HoO, Botanical Survey of India, Eastern Regional Centre, Shillong, are also acknowledged.

\section{Literature Cited}

Hallier, H. von 1922. Beiträge zur Kenntnis der Thymelaeacean under ihrer natürlichen Umgrenzung. Meded. Rijks-Herb. 44: 1-31.

Haridasan, K. \& R.R. Rao 1985. Forest Flora of Meghalaya. Bishen Singh Mahendra Pal Singh, Dehra Dun.

Hou, D. 1964. Notes on some Asiatic species of Aquilaria (Thymelaeaceae). Blumea 12(2): 285-288.

Ito, M. \& G. Honda 2005. Taxonomical identification of agarwood-producing species. Nat. Med. 59: 104-112.

IUCN, 2016 Guidelines for using the IUCN Red List Categories and Criteria. 2016, version12. Prepared by the Standards and Petitions Subcommittee. Downloadable from http://www.iucnredlist. org/documents/RedListGuidelines.pdf.

Joseph, J. 1982. Flora of Nongpoh. Forest Department of Meghalaya, Meghalaya.

Kanjilal, U.N., Kanjilal, P.C., De, R.M. \& A. Das 1940. Flora of Assam. Vol. 4. Government of Assam. pp. 112-113.
Kiet, L.C., Kessler, P.J. \& M. Eurlings 2005. A new species of Aquilaria (Thymelaeaceae) from Vietnam. Blumea 50(1): 135-141.

Mir, A.H., Iralu, V., Pao, N.T., Chaudhury, G., Khonglah, C.G., Chaudhary, K.L., Tiwari, B.K. \& K. Upadhaya 2016. Magnolia lanuginosa (Wall.) Figlar \& Noot. in West Khasi Hills of Meghalaya, northeastern India: Re-collection and implications for conservation. J. Threat. Taxa 8: 8398-8402.

Saikia, P. \& M.L. Khan 2013. Population structure and regeneration status of Aquilaria malaccensis Lam. in home gardens of upper Assam, NE India. Trop. Ecol. 54: 1-13.

Upadhaya, K. 2015. Structure and floristic composition of subtropical broad-leaved humid forest of Cherapunjee in Meghalaya, Northeast India. J. Biodivers. Managem. E Forest. 4: 4. http://dx.doi.org/2327-4417.1000149.

Upadhaya, K., Barik, S.K., Adhikari, D., Baishya, R. \& N.J. Lakadong 2009. Regeneration ecology and population status of a critically endangered and endemic tree species (Ilex khasiana Purk.) in north-eastern Indian. J. Forest. Res. 20: 223-228.

Upadhaya, K., Mir, A.H. \& V. Iralu 2017. Reproductive phenology and germination behaviour of some important tree species of Northeast India. Proc. Natl. Acad. Sci., India, Sect. B. Biol. Sci. doi: 10.1007/s40011-017-0841-4.

Received: 17.12.2015

Revised and Accepted: 20.12.2017 